\title{
Cyclam-Modified Polyethyleneimine for Simultaneous TGF $\beta$ siRNA Delivery and CXCR4 Inhibition for the Treatment of CCl4-Induced Liver Fibrosis [Corrigendum]
}

Ullah A, Chen G, Hussain A, et al. Int J Nanomedicine. The authors apologize for this error. 2021;16:4451-4470.

The authors have advised there is an error in the author list on page 4451. The text "Muhammad Usman," should read "Muhammad Usman,".

\section{Publish your work in this journal}

The International Journal of Nanomedicine is an international, peerreviewed journal focusing on the application of nanotechnology in diagnostics, therapeutics, and drug delivery systems throughout the biomedical field. This journal is indexed on PubMed Central, MedLine, CAS, SciSearch ${ }^{\mathbb{B}}$, Current Contents ${ }^{\mathbb{B}} /$ Clinical Medicine,
Journal Citation Reports/Science Edition, EMBase, Scopus and the Elsevier Bibliographic databases. The manuscript management system is completely online and includes a very quick and fair peer-review system, which is all easy to use. Visit http://www.dovepress.com/ testimonials.php to read real quotes from published authors. 